\title{
Etnobiologi dan Keragaman Budaya di Indonesia
}

\author{
Johan Iskandar \\ Fakultas MIPA Universitas Padjadjaran \\ johan.iskandar@unpad.ac.id
}

\begin{abstract}
As a scientific dicipline, ethnobiology has not yet well-developed in Indonesia. This article discusses the development of ethnobiology, biodiversity, and ethnic diversity in Indonesia as the foundation of Indonesian ethnobiological study. This article analyses the utilization and management of biodiversity by traditional community by presenting the case of space management among Sundanese and the influence of climate chage towards traditional peasant's response. This article also presens the normative analysis on the role of ethnobiology for multicultural development in Indonesia.
\end{abstract}

Keywords: Ethnobiology, Biodiversity, Ethnic diversity, Development

\begin{abstract}
Abstrak
Etnobiologi, sebagai disiplin ilmiah, belum banyak dikembangkan di Indonesia. Tulisan ini mengulas perkembangan disiplin etnobiologi dan keragaman hayati serta kebhinekaan suku bangsa sebagai landasan etnobiologi Indonesia. Selain itu artikel ini juga mengulas pemanfaatan dan pengelolaan keragaman hayati oleh masyarakat tradisional dengan contoh kajian etnobiologi pengelolaan tata ruang pada orang Sunda serta pengaruh perubahan iklim pada tanggapan petani tradisional, dan ulasan normatif tentang peranan etnobiologi bagi pembangunan multikutural di Indonesia.
\end{abstract}

Kata kunci: Etnobiologi, Keragaman hayati, kebhinekaan suku bangsa, Pembangunan

\section{Pendahuluan}

Etnobiologi dapat diartikan secara umum sebagai evaluasi ilmiah tehadap pengetahuan penduduk tentang biologi, termasuk di dalamnya pengetahuan tentang tetumbuhan (botani), hewan (zoologi) dan lingkungan alam (ekologi). Ditilik dari perkembangannya, etnobiologi merupakan disiplin ilmu yang relatif baru. Meski demikian, etnobiologi telah berkembang dengan sangat pesat. Kajian etnobiologi telah menjadi suatu kajian lintas disiplin yang khas dan luas, baik secara teori maupun praktik. Misalnya, kajian tentang jenis-jenis tumbuhan obat dan pengobatan tradisional, sistem keberlanjutan sumber daya alam, bencana alam, dan lainnya (Ellen 2006: 3). Jadi, kini etnobiologi tidak lagi mengkaji sekedar aspek-aspek biologi atau sosial penduduk secara parsial, tapi kini kajian etnobiologi umumnya dilakukan secara holistik, yakni kajian aspek-aspek sosial penduduk yang terintegrasi dengan sistem ekologi. Pasalnya, dalam mengkaji pengelolaan dan pemanfaatan sumber daya alam, seperti flora, fauna, dan ekosistem lokal, yang dilakukan oleh masyarakat pribumi, masyarakat lokal atau masyarakat tradisional, umumnya menyangkut aspekaspek sistem sosial dan ekosistem yang terintegrasi. Misalnya, menyangkut faktorfaktor pengetahuan lokal, pemahaman, kepercayaan, persepsi dan world view, bahasa lokal, pemilikan/penguasaan sumber daya lahan, sistem ekonomi dan teknologi, institusi sosial, serta aspek- 
aspek ekologis, seperti biodiversitas, pengelolaan adaptif, daya lenting, dan penggunaan sumber daya alam berkelanjutan.

Ditilik dari berbagai kajian etnobiologi secara lintas budaya di berbagai belahan dunia, pada umumnya masyarakat tradisional dengan berbekal modal pengetahuan lokalnya, seperti pengetahuan biologi lokal telah mampu dan berhasil melindungi proses-proses ekologi potensial, melindungi aneka ragam species atau varietas tumbuhan dan hewan, beserta ekosistemnya, untuk kepentingan ekonomi lokal mereka secara berkelanjutan. Oleh karena itu, tidaklah heran bahwa pengetahuan lokal, yang merupakan kajian utama etnobiologi sejak tahun 1990-an, telah banyak dikaji oleh berbagai kalangan untuk dimanfaatkan bagi berbagai program pembangunan, misalnya pada bidang pengobatan, pertanian, peternakan, kehutanan, dan konservasi alam (lihat Warren dkk 1995).

Selain itu, perhatian terhadap kajian etnobiologi juga kian meningkat seiring dengan perubahan mendasar paradigma pembangunan di berbagai negara di dunia, termasuk di Indonesia, yang mengadopsi pembangunan berkelanjutan. Hal itu terutama pasca diselenggarakannya Konferesi Tingkat Tinggi (KTT) Bumi tentang Lingkungan dan Pembangunan (the United Nations Conference on Environment and Development-UNCED) 1992, di Rio de Janeiro, Brasil. Hasil konferensi tersebut telah disepakati dan menjadi komitmen bagi semua negara di dunia, bahwa pembangunan parsial yang hanya menekankan pada pembangunan ekonomi diganti dengan paradigma pembangunan berkelanjutan, yaitu, pembangunan yang berusaha untuk memenuhi kebutuhan sekarang tanpa mengurangi kemampuan generasi yang akan datang untuk memenuhi kebutuhannya (WCED 1987). Pada pembangunan berkelanjutan, aspek ekonomi, sosial dan lingkungan hidup diintegrasikan.

Pada masa silam, sebelum sistem ekonomi pasar masuk deras ke berbagai pelosok pedesaan di Indonesia, pada umumnya hubungan timbal balik penduduk desa dengan sumber daya alam dan lingkungannya didasari oleh sistem kompleks yang disebut corpus-cosmospraxis (bandingkan Toledo 2002:514). Dengan kata lain, bahwa berbagai praktik penduduk (praxis) lokal dalam mengelola dan memanfaatkan sumber daya alam biasanya dilandasi kuat oleh sistem kepercayaan (cosmos) dan sistem pengetahuan/kognitif (corvus) mereka. Jadi, sejatinya meski tingkat pendidikan formal penduduk pedesaan di Indonesia rendah, tetapi dari segi pengalaman dan kearifan ekologi yang berlandaskan pada pengetahuan dan budaya lokal, mereka itu cukup 'terdidik'. Penduduk desa pada umumnya telah mampu memanfaatkan dan mengelola sumber daya alam dan lingkungannya secara berkelanjutan. Namun, sayangnya berbagai pengetahuan dan budaya masyarakat lokal, kini cenderung masih kurang diberdayakan dalam berbagai program pembangunan di Indonesia. Alih-alih diberdayakan kini berbagai program pembanguan di Indonesia cenderung diabaikan dan telah menyebabkan erosi pengetahuan lokal dan kerusakan lingkungan atau ekosistem.

Pada tulisan ini penulis akan menarasikan 5 aspek utama, yaitu a) gambaran umum tentang perkembangan etnobiologi, b) pengetahuan masyarakat tradisional dan kaitannya dengan kajian etnobiologi, c) keragaman hayati dan kebinekaan suku bangsa, bahasa dan pengetahuan lokal di Indondesia, d) pemanfaatan dan pengelolaan hayati oleh masyrakat tradisional, dengan contoh kajian etnobiologi tentang pengelolaan tata ruang orang Sunda dan pengaruh perubahan iklim pada petani tradisional, serta e) 
peranan etnobiologi bagi pembangunan multikutural di Indonesia.

\section{Perkembangan Etnobiologi}

Ditilik dari sejarah perkembangan etnobiologi paling tidak dapat dibagi 3 fase utama. Pada fase awal, periode sekitar 1870-an-1950-an, kajian etnobiologi umumnya lebih bersifat elementer. Pada masa itu, sejatinya kajian etnobiologi lebih fokus pada hubungan antara 'penduduk pribumi' (indigenous people) atau 'penduduk tradisional' dengan jenis-jenis tumbuhan dan binatang. Misalnya, mengkaji tentang nama-nama jenis tumbuhan dan binatang beserta penggunaannya oleh masyarakat tradisional non Barat. Kajian tersebut kerapkali dinamakan pula sebagai deskripsi pengetahuan biologi oleh 'penduduk primitif' (Castetter, 1944; Harrington, 1947; Stevenson, 1915; Ballic dan Cox, 1997; Cotton, 1996; Ellen, 2006). Kajian etnobiologi berkembang antara lain diawali dengan sejarah berbagai penjelajahan orang-orang Eropa, seperti penjelajahan Christopher Columbus (14921620) ke berbagai negara di luar Eropa, seperti Bahama, Cuba dan lainnya di masa silam. Mereka itu melakukan pengamatan dan pendokumentasian aneka ragam penggunaan jenis-jenis tumbuhan dan hewan oleh berbagai kelompok penduduk tradisional, sehingga berkembangnya ilmu pengetahuan baru, yang dinamakan etnobotani, yang pertama kali didefinisikan oleh Harsberger pada tahun 1895 (Cotton, 1996:6-7).

Pada fase kedua, sekitar 1950-1990-an, perkembangan studi etnobiologi lebih terfokus pada studi konsepsi manusia dan klasifikasi mengenai alam, suatu perkembangan sejalan dengan telah terbitnya disertasi doktor Harold Conklin pada tahun 1954. Menurut Nazera (1999), pada tahun 1954, Harold Conklin menulis suatu disertasi berjudul "Hanunoo Culture to the Plant World", hasil kajian lapangan pada komunitas Yagaw Hanunoo di Pulau Mindoro Selatan, Filipina. Pada tahun yang sama, Conklin memperkenalkan istilah 'etnoekologi'. Conklin menyajikan istilah etnoekologi dalam sebuah makalah yang mendiskusikan dan mengeritik pandangan umum masyarakat luas, yang memandang negatif terhadap sistem ladang berpindah (swidden cultivation). Pada umumnya sistem ladang berpindah dipandang oleh orang luar sebagai suatu pekerjaan serampangan, merusak lingkungan, ilegal dan 'cara primitif' masyarakat tradisional dalam menggarap lahan demi menopang kehidupannya. Padahal faktanya menurut Conklin sistem perladangan berpindah tersebut dikelola masyarakat tradisional dengan berlandaskan pengetahuan lokal yang sangat mendalam. Setelah itu, dari pertengahan limapuluhan hingga pertengahan tujuhpuluhan, ide Conklin tersebut mendapat berbagai sambutan. Lantas di dalam perkembangannya awalan (prefiks) 'etno' menjadi suatu kajian disiplin ilmu dengan pendekatan dari sudut pandangan penduduk lokal yang dikaji (pandangan emik) dan dievaluasi oleh sudut pandang orang luar peneliti dari aspek disiplin ilmu Barat (pandangan etik). Misalnya, etnobotani, dikaji tentang berbagai aspek botani dari sudut pandang penduduk lokal (emik), dengan dikaji oleh seorang peneliti (pandangan etik). Dengan kata lain, etnobotani merupakan evaluasi ilmiah terhadap pengetahuan penduduk mengenai botani. Lantas dalam perkembangannya, sejalan dengan terbitnya hasil kajian Conklin tentang sistem perladangan berpindah pada suku Hanunoo di Filipina, berkembang kajian yang dinamakan etnoekologi. Pada kajian etnoekologi ini, di antaranya mengkaji dan mendokumentasikan tentang sistem klasifikasi dari penduduk lokal (folk classification system). Misalnya, klasifikasi penduduk lokal tentang berbagai jenis tumbuhan, binatang, tanah, air, sakit, dan lain-lain. Tidak hanya itu saja, sistem klasifikasi penduduk lokal tersebut juga mencakup bentuk-bentuk lahan, tanah, 
iklim, tipe-tipe vegetasi, tingkatantingkatan suksesi ekologi vegetasi dan berbagai tataguna lahan (lihat Martin 1995).

Sementara itu, pada fase ketiga, setelah tahun 1990-an, etnobiologi kian berkembang lagi dengan lebih pesat. Misalnya menurut Ellen (2006), kini kajian etnobiologi dalam analisisnya lebih berkembang dengan bersifat narasi, dengan mendeskripsikan obyek kajian secara cermat. Sementara itu, beberapa teori etnobiologi telah berkembang pula secara khusus. Pada umumnya di dalam studi lapangan etnobiologi telah banyak menyerupai tata kerja dari teknik etnografi, seperti dengan teknik wawancara dengan informan penduduk tradisional dan teknik observasi partisipasi dalam berbagai kegiatan penduduk lokal atau penduduk tradisional. Namun, selain itu kajian etnobiologi juga mempunyai teknik pengumpulan data lapangan yang menyerupai tata kerja atau teknik pengumpulan data lapangan bidang biologi ekologi, seperti mengidentifikasi jenis-jenis tumbuhan, jenis-jenis hewan, dan membuat petakpetak analisis vegetasi hutan. Selain itu, telah terbit pula beberapa buku khusus tentang panduan lapangan untuk kajian etnobotani atau etnobiologi. Misalnya buku yang ditulis oleh Martin 1995; Alexiades dan Sheldon, 1996; Cunningham 2001; dan Iskandar (in prep.). Selain itu, berbagai pengetahuan tradisional yang menjadi fokus dalam studi etnobiologi sejak tahun 1990-an, telah banyak dikaji oleh berbagai kalangan untuk dimanfaatkan bagi berbagai program pembangunan, misalnya pada bidang pengobatan, pertanian, peternakan, kehutanan, dan konservasi alam, serta konservasi keanekaan hayati (lihat Warren dkk 1995).

\section{Fokus Kajian Etnobiologi}

Pada tahun 1990-an, sejalan dengan kian berkembangnya studi etnobiologi, telah muncul berbagai istilah untuk penduduk
non-Barat, seperti 'masyarakat atau penduduk lokal', 'penduduk tradisional', 'penduduk asli' atau 'penduduk pribumi' (indigenous people). Berbagai istilah tersebut untuk mengacu pada penduduk yang masih memegang tradisi yang ditransmisikan secara turun temurun dari satu generasi ke generasi berikutnya dalam kurun waktu yang sangat lama, berabadabad, tinggal dalam satu lingkungan lokal. Dengan kata lain, bahwa pada masyarakat tersebut terjadi proses keberlanjutan sejarah dan budaya mereka, termasuk kepercayaan, prinsip, tingkah laku dan berbagai praktik dari pengalaman sejarah yang sangat panjang (lihat antara lain Hunn 1993: 16; Berkes 1993; Berkes dan Folke 1998: 5).

Sama halnya dengan istilah masyarakat tradisional, pengetahuan tradisional (traditional knowledge) juga memiliki berbagai istilah, seperti 'pengetahuan penduduk penduduk asli' (indigenous konoweldge-IK), 'pengetahuan teknik indigenous' (indigenous technical knowledge), 'etnoekologi' (ethnoecology), 'pengetahuan lokal' (local konowledge), 'pengetahuan rakyat' (folk knowledge), 'pengetahuan ekologi tradisional' (traditional ecological knowledge-TEK), 'sains penduduk' (people scince) dan 'pengetahuan penduduk desa' (rural people knowledge). Pada umumnya, meskipun berbagai istilah pengetahuan tradisional (traditional knowledge-TK) tersebut belum sepenuhnya disepakati oleh berbagai kalangan, tetapi sebagai gambaran umum, beberapa sifat karakteristik dari IK/ TK (Ellen dan Harris 2002:4-5; Hunn 1993), diantaranya yaitu (1) IK/TEK sifatnya lokal, kebalikan global; (2) IK/EK ditransmisikan secara lisan dengan menggunakan bahasa ibu, dibandingkan bahasa tulis; (3) IK/TEK memiliki suatu komponen intuitif, kebalikan dengan murni rasional; (4) IK/TEK pada umumnya bersifat holistik, kebalikan dengan reduksionis; (5) IK/TEK biasanya pikiran dan materi 
dipertimbangkan bersama, kebalikan dengan pemisahan antara pikiran dan materi; (6) IK/TEK adalah menekankan pada moral, kebalikan dengan berdasakan dugaan nilai yang bebas; (7) IK/TEK lekat dengan spiritual, merupakan kebalikan dengan sifat mekanistis; (8) IK/TEK utamanya didasarkan pada observasi empiris dan akumulasi fakta-fakta diperoleh dengan trial and error, kebalikan dengan analisis; (9) IK/TEK didasarkan pada data dihasilkan oleh pengguna sumberdaya alam itu sendiri, kebalikan dengan suatu kader peneliti-peneliti atau asisten peneliti; dan (10) IK/TEK biasanya didasarkan pada data diakronik, yaitu rangkaian waktu panjang tentang informasi pada suatu lokasi, kebalikan dari data sinkronik, yaitu data dari daerah yang luas dari hasil kajian rangkaian masa yang singkat.

Pada umumnya sejak era tahun 1990-an, berbagai studi etnobiologi lebih banyak dikaitkan dengan kajian tentang pengetahuan lokal atau pengetahuan tradisional tentang lingkungan (Traditional Environmental Knowledge-TEK) yang dikaji sebagai landasan untuk pemanfaatan sumberdaya alam secara lestari demi pembangunan berkelanjutan (Hunn, 2002: 4; Sillitoe, 2006). Menurut Sillitoe (2006), kini studi etnobiologi tiba-tiba menemukan relevansi dirinya dalam menangani berbagai permasalahan dalam pembangunan berkelanjutan, seperti dalam bidang pengelolaan berbagai sumber daya alam, lingkungan, dan kesehatan. Kini telah disadari pula secara luas bahwa masyarakat lokal seyogianya diberi peran sentral, seperti yang ditunjukkan oleh sejumlah ahli etnobiologi yang telah memberikan perhatian terhadap programprogram pelestarian alam (Laird, 2002; Posey, 1999).

Tidak hanya itu, kini para agensi konservasi alam juga telah menyadari bahwa keanekaan budaya, pengetahuan dan praktik masyarakat tradisional memiliki kontribusi terhadap pemahaman dan proteksi lingkungan dan sumber daya alam serta keanekaan hayati. Misalnya, The World Heritage Convention, UNESCO, PBB telah memunculkan suatu kategori baru pada tahun 1995, tentang The Cultural Landscape, dengan mengakui hubungan yang kompleks antara manusia dengan alam dalam membentuk dan melindungi lanskap (Sillitoe, 2006). Contohnya, suatu studi kasus di Taman Buru di Africa, yang telah menyingkirkan penduduk pastoral dan kelompok pemburu peramu minoritas yang dianggap menjadi gangguan terhadap taman buru tersebut (Kassam dan Bashuna, 2004). Namun, faktanya dengan mengeluarkan penduduk tradisional dari kawasan taman buru, telah menyebabkan perubahan drastis dalam sistem ekologi lokal, yang merusak lingkungan taman buru yang dilindungi oleh para pengelolanya. Pasalnya berbagai aktivitas penduduk pastoral telah melindungi secara signifikan fungsi pengelolaan lubang-lubang sumber air tanah dan lahan penggembalaan mereka. Hal tersebut tidaklah sulit untuk dimengerti mengingat berbagai aktivitas manusia yang telah tinggal di daerah tersebut pusat penciptaan antropoid telah berlangsung untuk kurun waktu jutaan tahun.

Penduduk pastoral tinggal di sana telah melakukan berbagai praktek perlindungan alam, misalnya dengan menghormati pada kayu-kayu di sekitar aliran air dan mata air (Smith, Meredith \& John, 1996). Komunitas ilmiah dapat mengidentifikasi berbagai prioritas konservasi tersebut melalui survei dan lain sebagainya. Jadi, dalam upaya menetapkan spesies lokal penting dan isu-isu ekosistem, dibutuhkannya keterlibatan dari penduduk pribumi (Shiva, 1994). Pada dasarnya penting untuk melibatkan penduduk pribumi secara aktif dalam pengelolaan sumberdaya alam dan lingkungan. Hal tersebut sangat sejalan dengan paradigma pembangunan berkelanjutan, yaitu pro- 
lapangan kerja, pro-rakyat miskin, progender dan pro-lingkungan hidup.

\section{Etnobiologi dan Keragaman Hayati Indonesia}

Negara Indonesia merupakan salah satu negara yang unik di dunia. Mengingat Indonesia memiliki jumlah pulau yang banyak, serta mempunyai keragaman hayati dan kebinekaan budaya tinggi. Ditilik dari keragaman pulau, kini paling tidak telah tercatat tidak kurang dari 18.110 buah pulau dengan ukuran kecil dan besar di Indonesia. Namun, dari sejumlah pulau-pulau tersebut baru sekitar 5.707 pula yang telah diberi nama (Sastrapradja, 2010: 76). Di antara pulaupulau di Indonesia, 5 pulau di antaranya dikenal sebagai pulau besar, yaitu Sumatera, Jawa, Kalimantan, Sulawesi dan Papua. Kawasan Negara Kesatuan Republik Indonesia (NKRI) sebagai negara maritim, memiliki luas lautan mencapai 2/3 (75\%) dari seluruh kawasan Indonesia. Panjang pantai negara kita mencapai $81.000 \mathrm{~km}$. Karena itu, apabila peta kawasan NKRI ditumpang tindihkan di atas peta Amerika Serikat. Maka, tampak bahwa luas kawasan NKRI hampir sama dengan luas Amerika Serikat, hanya perbedaannya Indonesia adalah sebuah kepulau, sedangkan Amerika Serikat adalah sebuah daratan (Soemarwoto, 2006: 83).

Pada umumnya pada masing-masing pulau nusantara tersebut memiliki aneka ragam ekosistem, baik ekosistem alami ${ }^{1}$ maupun ekosistem binaan. Pada dasaranya aneka ragam ekosistem tersebut dapat dibedakan pula dalam 2 kategori utama, yaitu ekosistem darat (ekosistem terrestrial) dan ekosistem perairairan tawar dan bahari

\footnotetext{
${ }^{1}$ )Ekosistem alami yaitu ekosistem yang sedikit mendapat pengaruhan aktivitas manusia, seperti lautan, danau alami dan hutan primer, sedangkan ekosistem binaan adalah ekosistem yang mendapat pengaruhan atau pengelolaan manusia, seperti sawah, kebun, kolam dan lainnya.
}

(ekosistem akuatik). Ditilik dari kategori tersebut, paling tidak di Indonesia memiliki 47 tipe ekosistem alami terestrial yang membentang dari pesisir hingga wilayah pegunungan tinggi. Misalnya, ekosistem alami terestrial dapat dibedakan atas tiga macam kelompok vegetasi, yaitu vegetasi pamah/dataran rendah (0-1.000 m dpl); vegetasi pegunungan, terdiri pegunungan bawah (1.000-1.500 m dpl) dan pegunungan atas $(1.500-2.400 \mathrm{~m} \mathrm{dpl})$ dan vegetasi sub-alpin (2.400-5.000 $\mathrm{m} \mathrm{dpl}$ ); serta vegetasi monsun di daerah kering dengan curah hujan rendah (kurang dari $1.500 \mathrm{~mm} /$ tahun, dengan nilai evapotransipirasinya melebihi curah hujannya). Sedangkan keragaman ekosistem bahari di antaranya terdiri dari ekosistem pesisir, ekosistem pantai, ekosistem mangrove, padang lamun, estuaria, dan ekosistem laut terbuka. Sementara itu, ekosistem binaan di negara kita sangat beragam, di antaranya hutan tanam; macam-macam agroekosistem seperti ladang berpindah, sawah tadah hujan, sawah irigasi, sawah surjan, sawah rawa, sawah pasang surut, kolam, tambak, perkebunan, kebun, talum, dan pekarangan (Sasatrapradja, 2010: 92-118).

Dalam hal kekayaan hayati, Indonesia dikenal sebagai salah satu negara 'megadiversiti', negara yang memiliki keanekaan hayati yang tinggi di dunia. Berdasarkan keragaman tumbuhan (flora) di Indonesia, negara Indonesia yang termasuk kawasan Malesia mempunyai aneka ragam tumbuhan yang sangat tinggi, di antaranya dari tumbuhan berbunga saja telah tercatat sekurangnya 250.000 jenis (Tabel 1). Selain itu, tercatat banyak jenis tumbuhan yang sebarannya hanya ada di Indonesia, seperti suweg raksasa atau bunga bangkai (Amorphophalus titanum), merupakan jenis tumbuhan yang memiliki perbungaan terbesar di dunia. Jenis tumbuhan lainnya, jenis anggrek hitam (Coelogyne pandurata) yang merupakan jati diri Kalimantan Timur, hanya tumbuh secara alami di Kersik Luai, Kalimantan 
Timur. Dari jenis tumbuhan nilai ekonomis, tercatat beberapa jenis kayu nilai ekononomis khas dari Indonesia yang terkenal ke seluruh dunia, seperti ampupu (Eucalytus urophylla) dari Nusa Tenggara Timur dan mangium (Acacia mangium) dari Piru, Ambon. Tak kalah menariknya Indonesia juga telah terkenal sebagai gudang jenis-jenis tumbuhan obat dan pusat anekaragam jenis buah-buahan. Berbagai jenis tumbuhan obat yang telah terkenal di Indonesia, seperti koneng gede (Curcuma sp), kencur, dan laja (Aplinia galanga), mempunyai pusat persebaran di Indonesia. Selain itu, dikenal pula jenisjenis tumbuhan obat lainnya, berupa pohon pegagan, daun, buah atau biji, serta berupa tumbuhan obat berupa jenis-jenis pohon, seperti kedawung (Parkia javanica), kepuh (Sterculia foetida), pule pandak (Rauvolvia serpentine) dan mindi (Azadirachta indica). Sementara itu, Indonesia juga telah terkenal sebagai pusat persebaran jenisjenis buah-buahan tropis, seperti dukuh, manggis, mangga, durian, pisang, dan matoa (Sastrapradja, 2000: 119-122).

\begin{tabular}{lll}
\hline $\begin{array}{l}\text { Kelompok } \\
\text { Tumbuhan }\end{array}$ & Indonesia & Dunia \\
\hline $\begin{array}{l}\text { Bakteri, } \\
\text { Ganggang } \\
\text { Biru/Hijau }\end{array}$ & 300 & 400 \\
Fungi & 12.000 & 47.000 \\
Rumput Laut & 1.800 & 21.000 \\
Lumut & 1.500 & 16.000 \\
Paku & 1.250 & 13.000 \\
$\begin{array}{l}\text { Tumbuhan } \\
\text { Berbunga }\end{array}$ & 25.000 & 250.000 \\
\hline
\end{tabular}

Tabel 1. Jumlah Jenis Tumbuhan di Indonesia dan di dunia. Sumber: Sastrapradja (2010: 119)

Sama halnya dengan keanekaan jenis tumbuhan, ditilik dari keragaman hewan, Indonesia juga memiliki keanekaragaman hewan yang tinggi. Misalnya, Indonesia merupakan negara terbanyak memiliki jenis mamalia di dunia (515 jenis).

Keanekaan jenis burung di Indonesia telah tercatat 1519 jenis, merupakan negara yang memiliki keanekaan burung nomor empat, setelah Kolumbia (1721 jenis), Peru
(1701 jenis) dan Brazil (1622 jenis). Sementara itu, jenis reptilian di Indonesia tercatat (600 jenis), merupakan peringkat ke tiga di dunia, setelah Meksiko (717 jenis) dan Australia (686 jenis) (Koziell, 2001:16).

\begin{tabular}{|c|c|c|}
\hline $\begin{array}{l}\text { Mamalia } \\
\text { (Jumlah } \\
\text { Jenis) }\end{array}$ & $\begin{array}{l}\text { Burung } \\
\text { (Jumlah } \\
\text { Jenis) }\end{array}$ & $\begin{array}{l}\text { Reptilia } \\
\text { (Jumlah } \\
\text { Jenis) }\end{array}$ \\
\hline $\begin{array}{l}\text { Indonesia } \\
\text { (515) }\end{array}$ & $\begin{array}{l}\text { Columbia } \\
\text { (1.721) }\end{array}$ & $\begin{array}{l}\text { Meksiko } \\
(717)\end{array}$ \\
\hline $\begin{array}{l}\text { Meksiko } \\
\text { (449) }\end{array}$ & $\begin{array}{l}\text { Peru } \\
(1701)\end{array}$ & $\begin{array}{l}\text { Australia } \\
(686)\end{array}$ \\
\hline Brazil (428) & $\begin{array}{l}\text { Brazil } \\
(1.626)\end{array}$ & $\begin{array}{l}\text { Indonesia } \\
(\mathbf{6 0 0 )}\end{array}$ \\
\hline Zaire (409) & $\begin{array}{l}\text { Indonesia } \\
\text { (1.519) }\end{array}$ & India (383) \\
\hline Cina (394) & $\begin{array}{l}\text { Ekuador } \\
\text { (1.447) }\end{array}$ & $\begin{array}{l}\text { Kolumbia } \\
\text { (383) }\end{array}$ \\
\hline Peru (361) & $\begin{array}{l}\text { Venezuela } \\
(1.275)\end{array}$ & Ekuador (345) \\
\hline $\begin{array}{l}\text { Kolumbia } \\
\text { (359) }\end{array}$ & $\begin{array}{l}\text { Bolivia } \\
(1.250)\end{array}$ & Peru (297) \\
\hline India (350) & $\begin{array}{l}\text { India } \\
(1.200)\end{array}$ & $\begin{array}{l}\text { Malaysia } \\
\text { (294) }\end{array}$ \\
\hline Uganda (311) & $\begin{array}{l}\text { Malaysia } \\
(1.195)\end{array}$ & $\begin{array}{l}\text { Thailand } \\
\text { (282) }\end{array}$ \\
\hline $\begin{array}{l}\text { Tanzania } \\
\text { (310) }\end{array}$ & $\begin{array}{l}\text { Cina } \\
(1.195)\end{array}$ & $\begin{array}{l}\text { Papua.N.G. } \\
\text { (282) }\end{array}$ \\
\hline $\begin{array}{l}\text { Total Dunia } \\
(4.170)\end{array}$ & $\begin{array}{l}\text { Total } \\
\text { Dunia } \\
(9200)\end{array}$ & $\begin{array}{l}\text { Total Dunia } \\
(6.300)\end{array}$ \\
\hline
\end{tabular}

Tabel 2. Jumlah Jenis Hewan di Indonesia dan dunia. Sumber: Koziell (2001:16).

Secara sebaran geografi fauna, sebaran fauna Indonesia dapat dibedakan atas 3 kelompok utama, yaitu kawasan Indonesia Barat, kawasan Indonesia Timur dan kawasan Indonesia Tengah. Kawasan Indonesia Barat, seperti Sumatera, Jawa dan Kalimantan memiliki jenis-jenis binatang yang menyerupai jenis-jenis binatang di benua Asia, seperti badak Jawa (Jawa, Sumatera), macan loreng (Jawa, Sumatera), macan tutul (Jawa), beruang madu (Sumatera, Kalimantan), gajah (Sumatera, Kalimantan), badak Sumatera (Sumatera, Kalimantan), banteng (Jawa, Kalimantan), tapir (Sumatera), kutilang, burung merak, platuk dan tulungtumpuk. Kawasan Indonesia Timur memiliki jenis- 
jenis hewan yang mirip dengan jenis-jenis hewan di benua Australia, seperti kuskus, kanguru pohon, burung cendrawasih, dan burung kaswari. Sementara itu, di Indonesia Tengah, mempunyai banyak jenis-jenis binatang yang khas, berbeda dengan jenis-jenis binatang di Indonesia Barat maupun Indonesia Timur, seperti anoa, babi rusa dan burung maleo (bandingkan van der Zon, 1979).

\section{Kebinekaan Sukubangsa}

Indonesia, selain memiliki keanekaan ekosistem dan keanekaragaman hayati, juga memiliki keanekaan atau kebinekaan suku bangsa ${ }^{2}$ dan bahasa. Indonesia telah tercatat memiliki lebih dari 300 kelompok etnik. Aneka ragam kelompok etnik tersebut bermukim di berbagai lokasi/geografis dan ekosistem, seperti lingkungan pesisir dan pedalam atau perairan daratan. Sementara itu, berdasarkan bentuk mata pencahariannya berbagai etnik tersebut dapat dibedakan menjadi lingkungan sosial pemburuperamu, nelayan, berladang berpindah atau berladang berotasi, petani menetap, serta industri dan jasa (Purba, 2002: 34). Misalnya, berbagai kelompok pemburu dan peramu yang hidup di perairan, seperti Orang Laut di perairan sekitar Batam, Irang Sekak di perairan utara Pulau Bangka, dan Orang Bajau di sepanjang perairan sebelah timur Pulau Sulawesi. Berbagai kelompok masyarakat nelayan di Indonesia dicatat di berbagai kawasan pesisir. Contohnya, masyarakat nelayan di Bagan Siapi-api dari suku Cina, nelayan Marunda, Muara Karang dan Cilincing dari suku bangsa Betawi; nelayan Pelabuhan Ratu masih bagian dari suku Sunda,

\footnotetext{
2 ). Suku bangsa atau kelompopok etnik dapat diartikan sebagai komunitas yang bermukim di suatu daerah, memiliki sejarah yang sama. Mengadopsi kebudayaan yang kurang lebih sama, memiliki kepercayaan dan agama sama, mitos dan legenda sama, dan berbicara dengan satu bahasa. Juga mereka memiliki makanan dasar dan kebiasaan sama (Boedihartono 2008, dikutip oleh Sastapradja, 2010: 81).
}

nelayan Cilacap di pantai Selatan Jawa, nelayan Cirebon dan Gresik di pantai utara Jawa; masyarakat pesisir Pulau Seram, pesisir utara Irian Jaya, pesisir Sulawesi, pesisir Kepulauan Kei.

Berbagai masyarakat pemburu dan peramu di kawasan hutan di Indonesia, tercatat di antaranya Anak Dalam di Jambi, Orang Sakai di pedalaman Riau, Orang Punan di Kalimantan Timur, Orang Asmat di Pedalaman Irian Jaya bagian selatan; orang Nualu di Pedalaman Pulau Seram, Maluku. Berbagai kelompok masya-rakat peladang berpindah di Indonesia, dikenal di antaranya masyarakat Baduy di Banten Selatan, masyarakat Kasepuhan di Sukabumi Selatan bagian dari suku bangsa Sunda; peladang Talang Mamak di pedalaman Riau, bagian suku bangsa Malayu, masyarakat Kantu di Kalimantan Barat, bagian dari kelompok suku bangsa Dayak. Sementara itu, para petani penetap terutama para petani sawah di berbagai suku bangsa di Indonesia.

Pada umumnya tiap suku di Indonesia mempunyai bahasa lokal atau bahasa ibu yang berbeda-beda. Mengingat Indonesia memiliki lebih dari 30 suku bangsa, maka tak heran di Indonesia memiliki sekurangnya 655 bahasa lokal atau bahasa ibu. Jumlah bahasa lokal di Indonesia menempati peringkat ke dua dari 25 negara di dunia yang memiliki bahasa lokal di dunia yang memiliki keanekaan bahasa lokal endemik setelah Papua Guinea (847 bahasa) (Maffi 1999: 24). Dengan adanya berbahasa lokal telah menyebabkan berbagai kelompok etnik memiliki kemampuan untuk berfikir secara sistimatis dan teratur serta berkembangnya aneka ragam pengetahuan lokal di Indonesia. Misalnya, pengetahuan penduduk lokal tentang botani, seperti pengenalan jenis-jenis tumbuhan, pemanfaatan dan pengelolaannya. Pengetahuan penduduk tentang ekologi pertanian atau agroekosistem, seperti pengelolaan berbagai agroforestri tradisional, seperti 
pekarangan dan sistem talun-kebun di Jawa Barat; sistem dukuh lembur atau leuweung lembur di Baduy, Banten Selatan; kaliwo atau kalego di Sumba Barat; repong damar di Krui, Lampung; kaleka di Bangka dan Belitung, Sumatera; pelak di Kerinci Jambi, Sumatera; parak di Maninjau, Sumatera Barat; lembo atau simpukng atau lepu atau pun pulung bue di Kalimantan Timur, dan tembawang di Kalimantan Barat (lihat Iskandar, 1998; Iskandar, 2001; Iskandar 2008; de Forestra dkk 2000; Puri 2005; Sulaiman dan Sancin, 2007).

Selain itu, beberapa kelompok etnik di Indonesia juga telah memiliki pengetahuan lokal untuk mengelola kawasan hutan secara berkelanjutan, misalnya dikenal sistem pengelolaan hutan dengan sistem tanah ulen di masyarakat Dayak Kalimantan Timur (sistem zonasi hutan keramat pada masyrakat Baduy (Iskandar, 2009); dan sistem zonasi tradisional pada masyarakat Toro, di kawasan enclave Taman Nasional Lore, Sulawesi Tengah (Baso, 2009). Tidak hanya itu, beberapa kelompok masyarakat lokal dengan berbekal pengetahuan lokalnya telah mampu mengelola sumber daya air secara berkelanjutan, seperti sistem sasi di Maluku, Sulawesi dan Papua (Wahyono dkk, 2000), dan sistem lubuk larangan di Sumatera (Lubis, 2009).

\section{Etnobiologi dan Penataan Ruang Orang Sunda : Kasus 1}

Pada umumnya di dalam praktik (praxis) pemanfaatan dan pengelolaan keanekaan sumberdaya alam dan hayati, penduduk tradisional bisanya dilandasi oleh sistem keperacayaan (cosmos) dan sistem pengetahuan atau kognitif (corvus) tradisional (Toledo 2002: 514). Karena itu, tak heran bahwa masyarakat tradisional dalam melakukan pengelolaan hayati dilandasi oleh pengetahuan tradisional dan lekat budaya, serta pada umumnya mampu dan berhasil mengelola kehati secara mandiri dan berkelanjutan. Namun sayangnya akibat populasi penduduk yang berkembang kian padat, teknologi berkembang cepat dan ekonomi pasar berkembang pesat, sistem pengetahuan penduduk, dan pemanfaatan serta pengelolaan penduduk pribumi terhadap sumber daya hayati dan lingkungannya banyak yang telah tererosi dan berubah drastis. Konsekuensinya, pemanfaatan sumber daya hayati dan lingkungan cendurung tidak terlanjutkan. Pada subseksi berikutnya diberikan dua contoh kajian aspek etnobiologi, khususnya pada masyarakat Sunda di Jawa Barat dan Banten, seperti sistem pengelolaan tata ruang Orang Sunda dan pengaruh perubahan iklim pada para petani tradisional.

Dewasa ini bencana longsor dan banjir menimpa beberapa wilayah Tatar Sunda. Banjir tahunan di Bandung Selatan, misalnya, kerap kali menyebabkan banyak rumah penduduk terendam. Lantas, sejumlah wilayah Kabupaten Garut Selatan dilanda longsor. Akibatnya, puluhan rumah rusak berat, beberapa penduduk meninggal dunia, serta ribuan orang mengungsi. Sementara itu, pada tanggal 23 Februari 2010 tanah longsor menimbun sebagian besar permukiman di Kampung Dewata, Desa Tenjolaya, Pasirjambu, Kabupaten Bandung. Tanah longsor itu menyebabkan 33 orang meninggal dunia dan 11 orang tertimbun (Kompas, 3/3/2010).

Faktor bencana banjir dan longsor di Kampung Dewata itu pada umumnya akibat faktor alam, seperti curah hujan yang tinggi, daerah yang curam, dan struktur batuannya yang labil. Namun, perilaku manusia yang tidak bijaksana dalam pemanfaatan ruang dan pengelolaan dewasa ini juga memicu terjadinya bencana banjir dan longsor. Padahal sesungguhnya, para leluhurnya Orang Sunda pada masa silam punya kearifan ekologi dalam pemanfaatan tata ruang dan perilaku bijaksana terhadap lingkungannya. 


\section{Penataan Ruang}

Pada masa silam Orang Sunda sangat peduli terhadap penataan ruang untuk kehidupan sehari-hari. Hal ini, antara lain, dapat disimak dalam naskah Sanghyang Siksakandang Karesian (kropak 632) yang memberi wejangan agar manusia bijaksana dalam pemanfaatan ruang dan pengelolaan lingkungan. Berdasarkan naskah Sunda tersebut, telah dikenal tak kurang dari 19 kategori lahan yang harus dihindari untuk dibangun manusia, yang disebut "kotoran bumi”.

Lahan "kotor bumi" tersebut, antara lain, lahan sarongge (tempat angker), lemah sahar (tanah sanggar), sema (kuburan), catan ronggeng (lahan dengan lereng curam), garenggengan (permukaan tanah kering, tetapi di bawahnya lumpur), dandang wariyan (dandang berair berupa lahan legok yang sering tergenang air), lemah laki (tanah tandus yang curam), kebakan badak (kubangan, termasuk kolam besar), hunyur (bukit kecil), pitunahan celeng (tempat habitat babi), kalomberan (comberan) dan jarian (tempat buang sampah) (Murtiyoso, 1994).

Selain itu, telah dikenal pula pepatah Orang Sunda masa silam yang merupakan anjuran untuk memanfaatkan ruang secara bijaksana dan memelihara lingkungan. Contohnya, gunung kaian (gunung tumbuhi pepohonan yang rimbun), pasir talunan (bukit-bukit dikelola dengan budidaya sistem talun), sampalan kebonan (lahan terbuka luas dijadikan kebun), gawir awian (tebing-tebing syogianya ditanami bambu), daratan imahan (daerah datar untuk didirikan rumah), dan susukan caian (pelihara air di parit-parit untuk sumber mata air). Selain itu, legok balongan (derah cekungan yang banyak air sebagai kolam sumber air), walungan rawateun (sungaisungai dan sempadan dipelihara), dataran sawahan (lahan datar tanaman padi sawah), basir jagaeun (pantai dan laut dijaga dan lindungi), gunung teu meunang dilebur (gunung tidak boleh dihancurkan), lebak teu meunang dirusak (daerah lembah jangan dirusak), serta mipit kudu amit jeung ngala kudu menta (memungut dan memanen harus mohon izin).

Kini, kendati kian pudar, pengelolaan tata ruang lokal dan usaha konservasi alam mandiri masyarakat masih dapat ditemukan pada beberapa kelompok masyarakat Sunda. Masyarakat Kampung Dukuh, Garut Selatan, misalnya, mengenal pengelolaan tata ruang secara adat. Wilayahnya dibagi lima zona pemanfaatan. Zona tersebut adalah lahan garapan untuk bertani, lahan larangan berupa lahan hutan dengan makam karomah yang dikeramatkan, lahan titipan (awisan), berupa lahan yang dicadang-kan untuk awisan para pendatang, lahan tutupan berupa lahan lahan hutan untuk kepentingan ekologis, dan lahan cadangan bagi perluasan lahan pertanian (YP2AS, 2005).

Di Kampung Naga, Tasiklmalaya, secara adat wilayahnya dibagi menjadi tiga zona. Zona pertama adalah kawasan suci, tempat hutan keramat yang dikonservasi secara adat. Zona kedua adalah kawasan bersih atau daerah permukiman. Adapun zona ketiga adalah kawasan kotor, yaitu tempat mandi, mencuci, kolam pekarangan, dan kandang ternak (Suganda, 2006).

Pada masyarakat Kasepuhan Cibeduk, Sukabumi, tata ruangnya dibagi menjadi tujuh zona, yaitu leuweung titipan (hutan titipan), leuweung kolot (hutan tua), leuweung cadangan (hutan cadangan), kompleks keramat (situs), walungan (sungai), mata air dan lain-lain (Yogaswara, 2009).

Demikian pula di Baduy, Banten Selatan, wilayahnya secara adat dibagi menjadi beberapa zona berdasarkan kesakralannya. Kawasan leuweung gede/leuweung titipan, Pusaka Buana, Cikeusik dan Sasaka Domas di Cibeo dianggap penduduk 
Baduy sebagai paling sakral serta dimanfaatkan hanya untuk ziarah tahunan. Zona bagian luarnya juga dianggap sakral, yaitu kawasan Baduy Dalam, untuk bermukim dan ngahuma Orang Baduy Dalam atau Baduy Jero atau Urang Girang di Cikeusik, Cibeo dan Cikartawarna. Bagian luarnya lagi, berupa kawasan Baduy Luar, dihuni oleh orang Baduy Luar (Urang Baduy Panamping), dianggap kurang sakral. Sementara itu, bagian paling luar dari kawasan Baduy merupakan zona penyangga, yaitu Daerah Dangka, yaitu daerah enclave di desa-desa muslim, tetangga Baduy. Di samping itu, hampir setiap bukit, baik Baduy Dalam maupun Baduy Luar, juga dikelola dengan sitem zonasi.

Zona pertama, bagian lembah-lembah bukit, dijadikan permukiman dan hutan kampung di sekitar permukiman (dukuh lembur), yang tidak boleh dibuka dijadikan ladang (huma). Kawasan hutan di sempadan sungai juga dikonservasi Orang Baduy. Zona kedua, di atas permukiman, digunakan untuk berladang (ngahuma), serta tempat hutan sekunder bekas ladang/huma (reuma). Sementara itu, zona ketiga di puncak-puncak bukit berupa leuweung kolot pantang ditebang dijadikan huma (Iskandar, 1998; 2009). Jadi, dengan sistem pengelolaan tata ruang lokal yang bijaksana, kawasan hutan lebat milik masyarakat adat Sunda akan terpelihara cukup baik.

\section{Perubahan Tata Ruang}

Beberapa kelompok masyarakat adat tetap konsisten mempraktikkan pengelolaan tataruang dengan cukup baik dan dapat melestarikan lingkungan hutan. Namun, sungguh disayangkan, sebagian besar kelompok masyarakat lain cenderung kian tidak peduli terhadap pelestarian lingkungan.

Berbagai lahan yang pada masa silam pantang dibangun, seperti catang ronggeng (lahan curam), gunung, hunyur, dan sempadan sungai, kini tidak luput dibangun juga. Akibatnya, terjadi kerusakan hutan, banjir, longsor, dan sedimentasi besarbesaran di sungai-sungai. Sementara itu, dangdan wariyan (empang-empang dan situ) yang berfungsi penting sebagai resapan air kini banyak yang dialih fungsikan menjadi lahan terbangun sehingga timbul banjir cileuncang di manamana.

Oleh karena itu, demi mencegah bencana alam yang kian parah, memanfaatkan ruang sesuai dengan peruntukannya. Hal itu sejalan dengan konsep Orang Sunda dan konsep kekinian masyarakat Barat, yang kini banyak dikajadi dalam etnobiologi.

\section{Pemanasan Global dan Siasat Petani : Kasus 2}

Kini dampak pemanasan global dan perubahan iklim dunia bukan lagi sekedar ancaman. Namun, anomali iklim tersebut sudah menjadi kenyataan yang menimpa kehidupan kelompok masyarakat lintas budaya di berbagai belahan dunia (Crate dan Nuttal, 2009). Salah satu kelompok masyarakat yang paling rentan mengalami gangguan iklim yang kian tak menentu tersebut adalah petani. Pada waktu lalu hingga bulan Juli tahun 2010 hujan tak kunjung berhenti di musim yang semestinya kemarau. Hal tersebut ditenggarai akibat pengaruh anomali cuaca dan iklim akibat pemanasan global. Konsekuensinya timbul petaka ledakan hama wereng dan penggerek batang yang menyebabkan kegagalan puluhan ribuan hektar padi di beberapa tempat di pulau Jawa akibat kesemerawutan pola tanam dan tidak adanya masa jeda tanam seperti masa silam sebelum era Revolusi Hijau sebelum awal tahun 1970-an (Kompas 17/6/2010). 


\section{Fungsi Adaptif Petani}

Petani sawah di masa silam memiliki pengetahuan ekologi lokal mendalam tentang agroklimat. Petani di Tatar Sunda di masa silam, misalnya, biasanya mengandalkan indikator alam dalam menentukan pergantian musim. Contohnya, rasi bintang, seperti bintang tujuh, bintang kerti, atau bintang kartika (the pleiades) dan bintang bintang wuluku (the belt of orion); masa berbunga atau berbuah tumbuhan, seperti randu (Ceiba petandra); daur biak binatang dengan nyanyian suara serangga, seperti turaes (Cryptotympana acuta) dan tonggeret (Dundubia manifera), serta kehadiran burung-burung migrasi di desa. Tidak mengherankan, dikenal banyak ungkapan petani di Tatar Sunda tentang indikator perubahan musim dan penggarapan sawah. Contohnya, bintang kidang jeung kerti ka kulon totonden musim ngijih kudu ngamimitian nyawah (bintang kidang dan kerti bergerak kearah barat, pertanda awal musim hujan dan harus siap menggarap sawah). Maka, ketika musim hujan akan tiba, para tetua ahli tani di desa biasa memerintahkan warga untuk mulai menggarap sawah. Pada umumnya kegiatan diawali dengan sedekahan atau selamatan di setiap keluarga atau pun bersama-sama di tempat-tempat sakral, seperti hulu wotan dan cai nyusu. Pada dasarnya kegiatan sedekahan dan penghormatan petani terhadap tempattempat sakral sumber air tersebut memiliki fungsi adaptif petani. Sebab, hal itu mendorong kebersamaan dan kekompakan petani untuk melindungi sumber air serta bertanam padi secara serempak demi efisiensi penggunaan air dan pengendalian ledakan hama padi (bandingkan Lovelace, 1984: 1996).

Seusai panen padi pertama, musim hujan atau rendengan, untuk tanam padi berikutnya (morekat) petani biasanya sangat mempertimbangkan ketersediaan air di sawah. Sawah-sawah yang masih memiliki air berlimpah (sawah ledok atau sawah ranca), sebagai penyelangnya, biasa ditanami dulu dengan ikan. Sementara sawah tadah hujan (sawah guludug atau geledugan), sebagai penyelangnya, umumnya ditanami palawija.

Penanaman ikan, seperti ikan mas, mujair, dan nila dilakukan petani langsung saat padi selesai dipanen atau ketika sawah baru ditanam padi (mina padi). Tanam ikan pascapanen padi tersebut sangat menguntungkan secara ekologis dan ekonomis. Secara ekologis sesusai panen padi, sawah sangat kondusif untuk ditanami ikan. Sisa-sisa jerami yang membusuk di sawah dapat memacu pertumbuhan plankton sebagai makanan ikan sehingga memacu pertumbuhan ikan di sawah. Selain itu, dengan adanya ikan, tanah sawah menjadi gembur. Jadi, waktu sawah digarap ulang, tanah mudah dicangkul atau dibajak. Tanahnya pun subur serta sangat baik bagi pertumbuhan tanaman padi.

Masa jeda tanam padi juga dapat memotong daur hidup hama padi. Selain itu, kehadiran ikan di sawah sebelum dicangkul atau dibajak ataupun sesaat setelah tanam padi dapat berfungsi memangsa serangga hama. Sementara itu, keuntungan ekonomisnya, ikan dari sawah tersebut berguna untuk konsumsi keluarga atau pun dijual. Berbeda dengan sawah ledok, setelah panen padi, sawah geledugan biasanya ditanami tanaman palawija, seperti jagung, ubi jalar, kacang panjang dan mentimun. Sebab, tanaman palawija tidak membutuhkan banyak air, tahan kekeringan, dan sangat bermanfaat untuk memulihkan kesuburan tanah serta memutuskan daur hidup hama padi, seperti wereng coklat.

\section{Tergerus Revolusi Hijau}

Pada akhir 1960-an keteraturan pola tanam padi sawah mengalami perubahan drastis karena diperkenalkannya berbagai varietas 
benih padi unggul hasil impor dari Filipina melalui program Revolusi Hijau. Pengenalan varietas padi baru tersebut menyebabkan sejumlah perubahan, seperti tidak seragam dan acak-acakannya pola tanam padi, rentannya ketersediaan air di musim kemarau, serta ledakan berbagai hama, seperti hama wereng (bandingkan Lansing, 1991).

Selain itu, Revolusi Hijau mengakibatkan kepunahan beragam varietas padi lokal karena tergusur benih padi komersial yang harus dibeli petani. Padahal sebelum Program Revolusi Hijau di seluruh tanah air Indonesia telah tercatat lebih dari 8.000 varietas padi lokal yang telah dibudidayakan para petani tradisional dengan berlandaskan pengetahuan etnobiologi hasil pewarisan secara turun temurun (bandingkan Fox, 1991: 64). Pupuk organik pun digantikan pupuk pabrikan. Tenaga kerbau kalah bersaing dengan traktor yang rakus bahan bakar minyak bumi, yang dimasa depan bakal kian langka. Biopestisida hasil racikan petani digantikan pestisida pabrikan yang meracuni organism musuh alami hama padi serta mencemari air sawah. Akibatnya teknologi mina padi yang adaptif dan menguntungkan petani kian sulit dipraktikan di sawah yang telah dipenuhi racun pestisida.

Revolusi Hijau juga telah mengorbankan petani generasi tua yang sarat pengalaman lapangan dalam bidang etnoekologi atau etnobiologi. Pasalnya, orang tua yang awalnya merupakan sumber generasi muda menimba pengetahuan ekologi lokal atau etnobilogi, serta pengetahuan hidup mencari nafkah pedesaan telah diabaikan. Generasi muda seolah-olah tidak lagi menerlukan lagi pengetahuan ekologi tradisional yang dianggap pengetahuan kolot. Akibatnya, program Revolusi Hijau itu tidak saja gagal mengangkat kesejahteraan dan menjaga kemandirian petani, tetapi juga mengikis habis pengetahuan ekologi lokal atau etnobiologi petani (bandingkan Winrato 2011). Padahal, pengetahuan petani ekologi lokal tersebut berfungsi adaptif bagi petani terhadap lingkungannya, terutama untuk mengahadapi perubahan iklim.

\section{Kesimpulan: Peran Etnobiologi Dalam Pembangunan}

Berdasarkan uraian terdahulu dapat disimak bahwa negara Indonesia memiliki keanekaan sumber daya hayati dan kebinekaan suku bangsa dengan aneka ragam pengetahuan ekologi atau biologi lokalnya. Hal itu sungguh penting untuk dapat dimanfaatkan bagi pembangunan berkelanjutan di Indonesia. Pada pembangunan berkelanjutan pada dasarnya, tidak hanya menekankan pada pembangunan ekonomi saja, tetapi harus memperhatikan pula aspek sosial budaya dan lingkungan hidup secara terintegrasi. Karena itu, pembangunan tersebut harus bersifat bottom-up, dengan mensyaratkan perlunya kerlibatan masyarakat, termasuk berbagai kelompok penduduk pribumi secara aktif. Maka, tidaklah heran bahwa sejak era tahun 1990-an, telah berkembang berbagai kajian masyarakat desa, di antaranya berupa pengkajian penduduk desa secara partisipatif (Pariticipatory Rural Apparaisal-PRA), yang dapat dimanfaatkan untuk menunjang program pembangunan. Sejalan dengan itu, pada periode yang sama, berbagai kajian pengetahuan indigenous (indigenous knowledg-IK), pengetahuan lokal (lokal knowledge) atau pengetahuan ekologi tradisional (traditional ecological knowledge-TEK), banyak dikaitkan untuk kepentingan praktis bagi menunjang pembangunan. Bahkan sejak tahun 1990an, berbagai kajian pengetahuan lokal, seperti etnobiologi banyak dibahas bagi kepentingan praktis untuk menunjang pembangunan. Pasalnya, kini kajian etnobiologi dalam perkembangannya telah menjadi ilmu pengetahuan yang kian kompleks dan tertintegrasi secara interdisiplin dengan berbagai bidang ilmu 
lain, seperti biologi, antropologi, linguistik, pertanian, farmasi, kedokteran dan lainnya. Oleh karena itu, banyak manfaat yang dapat diperoleh dengan kajian etnobiologi, baik secara akademik, maupun secara teknis. Secara akademik, etnobiologi kini telah menjadi ilmu pengetahuan yang kian holistik dan menjadi lebih tertintegrasi dengan berbagai disiplin ilmu lainnya.

Sementara itu, secara praktis, etnobiologi kian penting untuk menunjang pembangunan berkelanjutan di Indonesia, seperti dalam bidang pertanian dan kesehatan, dengan memanfaatkan kekayaan sumber daya alam hayati dan sumber daya modal sosial masyarakat, seperti pengetahuan ekologi atau biologi lokal dari kebinekaan suku bangsa nusantara, demi mencapai masyarakat Indonesia yang sejahtera secara berkeadilan.

\section{Daftar Pustaka}

Alexiades, M.W and J.W. Sheldon. (1996). Selected Guidelines for Ethnobotanical Research: A Field Manual. Bronx : The New York Botanical Garden.

Balick, M and P.A. Cox. (1997). Plants, People, and Culture: The Science of Ethnobotany. New York: Scientific American Library.

Baso, G. (2009). Mophilonga Katuvua: Konsepsi Masyarakat Adat Toro Dalam Mempertahankan Kelestarian Sumberdaya Hutan, dalam Soedjito, H., Y. Purwanto, E.Sukara (eds), Situs Keramat Alami: Peran Budaya Dalam Konservasi Keragaman Hayati. Jakarta: Yayasan Obor Indonesia, Pp. 240-266.

Berkes, F. (1993). Traditional Ecological Knowledge in Perspective, dalam J.T. Inglis (ed), Traditional Ecological Knowledge: Concepts and Cases. Ottawa: International Program on Traditional Ecological Knowledge. Pp. 1-9.

Berkes, F. and Folke. (1998). Linking Social and Ecological Systems for Resilience and Sustainability. Dalam F.Berkes and C.Folke (eds), Linking Social and Ecological Systems: Management Pracitices and Social Mechanisms for
Building Resilience. Cambridge:

Cambridge University Press. pp.1-25.

Castetter, E.F. (1944). The Domain of Ethnobiology. American Naturalist 78: 158-170.

Cotton, C.M. (1996). Ethnobotany: Principles and Applications. England: John Willey and Sons.Ltd.

Crate, S.A. and M.Nuttall (eds). (2009). Anthropology and Climate Change: From Ecounters to Actions. California: Left Coast Press.

Cunningham, A.B. (2001). Applied Ethnobotany: People, World Plant Use \& Conservation. London and Sterling: Earthscan Publication

de Forestra,H., A.Kusworo, G.Michon dan W.A. Djatmiko. (2000). Ketika Kebun Berupa Hutan: Agroforest Khas Indonesia Sebuah Sumbangan Masyarakat. Bogor: International Centre for Research in Agroforestry (ICRAF).

Ellen, R.F. (2006). Introduction. Royal Anthropological Institute (ns): S1-S22.

Ellen, R.F and H.Harris. (2000). Introduction. Dalam R.F. Ellen, P. Parkes, A.Bicker (eds), Indigenous Environmental Knowledge and its Transformation: Critical Annthrophological Perspective. Amsterdam: Hardwood Academic Publishers.

Fox, J. J. (1991). Managing the Ecology of Rice Production in Indonesia. Dalam Hardjono, J. (ed), Indonesia: Resources, Ecology, and Environment. Singapore: Oxford University Press. Pp. 61-103.

Harrington, J.P. (1947). Etnobiology. Acta Americana 5: 244-7.

Hunn, E. (1993). What is traditional ecological knowledge?. In N.M. Williams and G. Baines (eds), Traditional Ecological Knowledge: Wisdom for Sustainbale Development. Canbera: Center for Resource and Environmental Studies, Australian National University. Pp. 13-15.

Hunn, E. (2002). Traditional Environmental Knowledge: Alienable or Inalienable Intelectual Property. Dalam J.R. Stepp, F.S. Wydham, and R.K.Zarger (eds), Ethnobiology and Biocultural Diversity. Georgia: Universty of Georgia Press.

Iskandar, J. (1998). Swidden Cultivation as a Form of Cultural Identity: The Baduc Case. Ph.D thesis, University of Kent at Canterbury. 
Iskandar, J. (2001). Manusia Budaya dan Lingkungan: Kajian Ekologi Manusia. Bandung: Humaniora Utama Press.

Iskandar, J. (2009). Pelestarian Daerah Mandala dan Keragaman Hayati Oleh Orang Baduy. Dalam H.Soedjito, Y.Purwanto, E.Sukara (eds), Situs Keramat Alami: Peran Budaya Dalam Konservasi Keragaman Hayati. Jakarta: Yayasan Obor Indonesia, Pp. 86-110.

Iskandar, J. (2009a). Ekologi Manusia dan Pembangunan Berkelanjutan. Bandung: Program Studi Magister Ilmu Lingkungan, Universitas Padjadjaran.

Iskandar (in prep.). Etnobiologi dan Pembangunan Berkelanjutan. Bandung: Pusat Penelitian Kebijakan Publik dan Kewilayahan, Unpad.

Kassam, A. \& B.A. Bashuna. (2004). Marginalisation of the Waata Oromo Hunter-Gatherer of Kenya: insider and outsider perspective. Africa 74: 194-216.

Koziell, I. (2001). Diversity not Adversity: Sustaining Livelihoods with Biodiversity. London: IIED.

Lair, S. (ed). 2002. Biodiversity and Traditional Knowledge. London: Earthscan.

Lansing, J.S. (1991). Priests and Programmers: Technologies of Power in the Engineered Landscape of Bali. Princeston, New Jersey: Princeston University Press.

Lovelace, G.W. (1984). Cultural Beliefs and Management of Agroecosystems. Dalam Rambo, A.T. dan P.E. Sajise (eds), An Introduction to Human Ecology Research on Agricultural Systems in Southeast Asia. Hawaii: East-West Environment and Policy Institute. Pp. 194-205.

Lubis, Z.B. (2009). Lubuk Larangan: Revivalisasi Situs Keramat Alami di Kabupaten Mandailing Natal. Dalam H.Soedjito, Y.Purwanto, E.Sukara (eds), Situs Keramat Alami: Peran Budaya Dalam Konservasi Keragaman Hayati. Jakarta: Yayasan Obor Indonesia, Pp.165191.

Maffi, L. (1999). Linguistic Diversity. Dalam Posey, D. (ed), Cultural and Spiritual Values of Biodiversity. London: Intermediate Technology Publications. Pp 21-35.

Martin, G.J. (1995). Ethnobotany: A Methods Manual. London: Chapman \& Hall.
Murtiyoso, S. (1994). Klasifikasi Lahan Pada Masyarakat Sunda Kuno, Sangyang

Siksakandang Karesian. Dalam K.Adimihardja (ed), Sistem Pengetahuan dan Teknologi Rakyat: Subsistensi dan Pembangunan Berwawasan Lingkungan di Kalangan Masyarakat Sunda di Jawa Barat. Bandung: Ilham Jaya Pp. 61-70.

Nazarea, V. (ed). (1999). Introduction A View From a Point: Ethnoecology as Situated Knowledge. Dalam Nazarea, V (ed), Ethnoecology: Situated Knowledge/Located Lives. Arizona: The University of Arizona Press Tuscon.Pp. 120.

Posey, D.A. (ed). (1999). Cultural and Spiritual Values of Biodiversity. London: Intermediate Technology Publications (for the UN Environment Programme).

Purba, J. (ed). (2002). Pengelolaan Lingkungan Sosial. Jakarta: Yayasan Obor Indonesia.

Puri, R.K. (2005). Deadly Dances in the Bornean Rainforest: Hunting knowledge of the Penan Benalui. Leiden: KITLV Press.

Sastrapradja, S.D. (2010). Memupuk Kehidupan di Nusantara: Memanfaatkan Keragaman Indonesia. Jakarta:

Shiva, V. (ed). (1994). Biodiversity Conservation :whose resources?. Whose knowledge?. New Delhi: INTACH.

Sillitoe, P. (2006). Ethnobiology and applied Anthropology: rapprochement of the academic with practical. J.Roy.Anthrop.Inst (N.S), S119-S142

Smith, W. T.C. Meredith, T.John. (1996). Use and conservation of woody vegetation by the Batemi of Ngorongoro district, Tanzania. Economic Botany 50, 290-9.

Soedjito, H. (2009). Tanah Ulen dan Konsep Situs Keramat Alami Studi Kasus di Desa Setulang, Kabupaten Malinau, Kalimantan Timur. Dalam H.Soedjito, Y.Purwanto, E.Sukara (eds), Situs Keramat Alami: Peran Budaya Dalam Konservasi Keragaman Hayati. Jakarta: Yayasan Obor Indonesia, Pp.267-280.

Soemarwoto, O. (2006). Pembangunan Berkelanjutan: Antara Konsep dan Reaitas. Bandung:Unpad.

Stevenson, M.C. (1915). Ethnobotany of the Zuni Indians. Bureau of American Ethnology Annual Report 30,31102. Washington DC: Government Printing Office. 
Suganda, H. (2006). Kampung Naga Mempertahankan Tradisi. Bandung: Kiblat Utama.

Sulaiman.S dan I. Sancin, (2007). Mengulas Tanah Adat Bangka Belitung Masyarakat Yang Tak Beradat. Pangkal Pinang: Bangka Pos, 16/9/2007.

Toledo, V.M. (2002). Ethnoecology: A Conceptual Framework for the Study of Indiginous Knowledge of Nature. Dalam J.R. Stepp, F.S. Wyndham, and R.K. Zarger (eds), Ethnobiology and Biocultural. Georgia: The International Society of Ethnobiology.

Van der Zon, A.P.M. (1979). Mammalia of Indonesia. Bogor: UNDP/FAO, National Park Development Project.

Warren, D.M., L.J. Slikkerveer and D.Brokensha (eds). (1995). The Cultural
Dimensions of Develoment: Indigenous Knowledge Systems. London: Intemediate Technology Publications.

WCED. (1987). Our Common Future. The Report of the Commission on Environment and Development. Oxford: Oxford University Press.

Winarto, Y.T, (ed). (2011). Bisa Dewek: Kisah Perjuangan Petani Pemulia Tanaman di Indramayu. Depok: Gramata Publishing.

Yogaswara, H. (2009). Situs Keramat Alami Sebagai Alternatif Pengakuan Hak-Hak Masyarakat Adat: Kasus Kasepuhan Cibedug, Banten, dalam H.Soedjito, Y.Purwanto, E.Sukara (eds), Situs Keramat Alami: Peran Budaya Dalam Konservasi Keragaman Hayati. Jakarta: Yayasan Obor Indonesia, Pp. 112-129. 